into a section of monosemantic words and a section of polysemantic words, the monosemantic word section being further subdivided into groups of terms belonging to particular spheres of seience and a group of widely used monosemantic words. The third peculiarity of the dictionary is that it contains not only a list of lexical units (words) but also a definite set of grammatical characteristics for each word, which is not fully formalized in ordinary dictionaries. This kind of dictionary also provides a system of relative word values, relating the lexical system of the target-language to that of the source-language. This is closely related to the fact that the dictionary provides 'zero values' for words, that is to say, those cases when a word should not be translated as a separate lexical unit.

\section{Mineralogy in the U.S.S.R.}

Is an article published in the Bull. All-Union Miner. Soc. $(88,609 ; 1959)$, V. F. Alyavdin, after giving a review of the present-day reference books on erystallography and mineralogy, such as those of Dana, Hintze, Doelter, Goldschmidt and Groth, as well as all the important periodical publications, suggests the necessity of publishing a special series of reference books, but in this case, dealing only with minerals and crystals found in the U.S.S.R. This, proposed, series is as follows: (1) Mineralogy of the U.S.S.R. (in 12-15 volumes); (2) Atlas of crystals of minerals in the U.S.S.R. (in $3-4$ volumes); (3) Chemical composition of minerals of the U.S.S.R. (in 2-3 volumes); (4) Optical mineralogy with determinative tables according to the immersion method and according to Fedorov's method; (5) Crystal-goniometric deter'minative tables, representing the continuation of the Boldyrev's tables for minerals of lower syngonies. At the end of his article V. F. Alyavdin provides a list of Russian publications dealing with regional mineralogy, since the publication of N. Y. Koksharov's "Materials for the mineralogy of Russia (1853-1891)". This list includes numerous publications on the minerals of the Kola. Peninsula, Crimea, Urals, Altai and other regions.

\section{Bio-electric Potentials of Plants}

IN earlier papers, D. S. Fensom (Canad. J. Bot., $35,573 ; 1957 ; 36,367 ; 1958)$ discussed the possible relationships between the bio-electric potentials in plants and translocation systems, and demonstrated that correlations exist between transport patterns and biopotential patterns. While the evidence did not prove conclusively that transport is due to internally generated electricity, it suggested that the two are closely linked, and that both are related to metabolism. Other investigators have advanced somewhat similar views. In a further paper, Fensom (Canad. J. Bot., 37, 1003; 1959) has considered the phenomenon of the production of continuous potentials across membranes in plant tissues by the circulation of the hydrogen ion. Of the three types of membranes which occur generally in plant cells, lipoid, protein and cellulose, it would seem that a protein-coated grid of cellulose can be envisaged as surrounding the cells. Such a membrane would appear to have the right pore size and properties to allow almost unfettered hydrogen ion diffusion but yet permit intercell biopotentials to be built up. It is pointed out that the most important ion involved in diffusion and in subsequent ion exchange would seem to be the hydrogen (as hydronium) ion, and that tissue can conveniently be divided into general areas of hydrogen ion production or hydrogen ion absorption. The resulting circulation of this ion is explored and discussed in relation to photosynthesis, respiration, protoplasmic streaming, and transport. These ideas are shown to give reasonable explanations for the results obtained in experiments and to resolve certain difficulties related to biopotential studies. They are considered to be useful since they predict some important results which can be experimentally tested, some of which are here given.

\section{Griseofulvin}

IN his presidential address to the British Mycological Society (Trans. Brit. Mycol. Soc., 43, 1; 1960), Dr. P. W. Brian presented a history of the research into griseofulvin. One is led behind the scenes and given an example of how initial interest. and careful choice of materials can play an important part in subsequent developments. The reference list shows that workers in a variety of fields have found it a profitable subject for research. Academic aspects that have attracted attention are its ehemistry, leading to synthesis of homologues, its mode of action, reflecting upon the normal constitution and development of fungal cell walls, and its translocation in angiosperms, bearing upon the relationship between molecular structure and ease of transport. The applied aspects recorded centre on its use as a systemic fungicide in the treatment of fungus diseases of plants and animals. Its importance in the growth of the concept of systemic fungicides is well known, and its use in animals, particularly against diseases like ringworm of cattle which are resistant to topically applied fungicides, promises to revolutionize treatment of animal mycoses.

\section{Priapulus caudatus Lamarck}

The discovery of $P$. caudatus, which was found for the first time in the Flatford area on March 1, 1958, is announced (Trans. Suffolk Nat. Soc,, 11, Part 2; 1959). A single specimen was taken from soft mud just below mean sea-level on the shore of the Stour estuary at Stutton Ness. Afterwards, it was proved to be widespread on both Suffolk and Essex shores of the estuary and occurs intertidally in small numbers wherever there is a suitable substrate of soft mud. No individuals have been taken from the region of lowered salinities above Brantham. In addition to the animals from the Stour, P. caudatus has been found in the mud of the large lagoon at Shingle Street in Suffolk and from a similar habitat by the Wade at Hamford Water, Essex. The "Victoria History of Suffolk" (1911) notes that this animal is common in the mud of the Deben at Waldringfield. Priapulus is an unusual unsegmented worm. The genus appears to have only slight affinities with other groups of invertebrates and is usually placed in a phylum of its own-phylum Priapulida.

\section{CIBA Foundation}

THE soventy-fifth anniversary issue of the Journal of the CIBA Foundation, the publication of the chemical firm in Basle, givos an account of the development of the concern, and also brief historical sketches of the branches of seience which are concerned in its processes. The Journal is richly illustrated, largely in eolour, and although some of the text is in the style of popular journalism, it is on 